\title{
Kent Meydanlarının Geçmiş ve Günümüz Görüntülerinin Görsel Peyzaj Kalitesinin Saptanması: İstanbul İli Taksim Meydanı Örneği
}

\section{Determination of Visual Landscape Quality of Past and Present Images of City Squares: The Example of Istanbul Taksim Square}

\section{Belma ACARLIa ${ }^{a}$ Tuğba KİPER ${ }^{\text {b* }}$}

aüksek Peyzaj Mimarı,Namık Kemal Üniversitesi, Güzel Sanatlar, Tasarım ve Mimarlık Fakültesi, Peyzaj Mimarlığı Bölümü, Tekirdağ, Türkiye

bProf. Dr. Namık Kemal Üniversitesi, Güzel Sanatlar, Tasarım ve Mimarlık Fakültesi Peyzaj Mimarlığı Bölümü, Tekirdağ, Türkiye

\section{ÖZET ABSTRACT}

Araştırmada, İstanbul İli için önemli bir tarihi birikime sahip Taksim meydanı ve yakın çevresinin; geçmiş ve günümüz durumunun görsel peyzaj kalitesine ilişkin değişimi irdelenmiştir. Bu doğrultuda çalışmada; alana ilişkin eski ve yeni kent görünümleri açısından görse peyzaja ilişkin algısal farklılıklar saptanmıştır. Çalışma kapsamında görsel peyzaj analizi yöntemi kullanılmıştır. Bu kapsamda Taksim Meydanı ve yakın çevresinde yer alan kentsel kimlik açısından önem teşkil eden Taksim Meydanı, Taksim Maksemi, İstiklal Caddesi, Cumhuriye Caddesi, Gezi Parkı, Atatürk Kültür Merkezi, The Marmara Oteli'ne ait 7 şer adet fotoğraftan oluşan geçmiş ve günümüze ilişkin görüntüler uzman grubu tarafından 5 ana 18 alt parametre temelinde $5^{\prime}$ li Likert ölçeğ kullanılarak değerlendirilmiştir. Tanımlayıcı istatistik değerlendirmeler sonucunda, en çok ve en az tercih edilen geçmiş ve günümüz görünümlerine ilişkin mekânsal karakteristikler tespit edilmiştir.

Anahtar Kelimeler: Meydan, Kent Meydanı, Görsel

Peyzaj Analizi, Taksim Meydanı
In this research; Taksim Square and its immediate surroundings, which has an important historical accumulation for the city of Istanbul, and its change in visual landscape quality is scrutinised by comparing the past and present situation. In this direction, the study reveals the perceptual differences related to the visual landscape in terms of old and new urban appearances of the area. The study adopts the method of visual landscape analysis. Within this framework, the past and today's images, which consist 7 photographs belonging to Taksim Square and its nearby places including Taksim Court, Istiklal Street, Cumhuriyet Street, Gezi Park, Ataturk Culture Centre, The Marmara Hotel as they are important in terms of urban identity, were evaluated by a group of experts using a 5-point likert scale based on 5 main parameters and 18 sub-parameters. As a result of the descriptive statistical assessments, the least and the most preferred spatial characteristics regarding both past and present appearances were determined.

Keywords: Square, Public Square, Visual Landscape Analysis, Taksim Square.

\section{GİRIŞ}

Meydanlar, kentte toplanma/dağılma merkezi oluşturma, görsel çekicilik gibi işlevlerinin yanısıra, özellikle; hem kent halkı hem de diğer ziyaretçiler için tanışma, bir araya gelme, toplanma, karşılaşma mekanları olmuşlardır. Öyle ki Erdönmezer (2014) meydanları; binalar arasında sosyal bir hayat (doku) yaratan mekanlar olarak tanımlamıştır. Böylelikle insanların şehrin karmaşasından kopup soluklandıkları, rahatlama ve dinlenme imkânı buldukları, insanların birbirini izledikleri ve kentteki olup biten olayları paylaştıkları çok amaçlı kullanım mekânları olmuşlardır. Bu noktada meydanlar antik dönemlerden Cumhuriyetin ilk dönemlerine kadar; agora, forum, plaza, campo, piaza, grand place olarak adlandırılan meydanlar; kentlerin yaşam felsefesini, yaşam tarzını yansıtan kent kültürünün önemli bir parçası olmuşlardır (İnceoğlu, Aytuğ, 2009; Atalay, 2011; Özer ve Ayten, 2005, Apak ve Erdönmez, 2015). Özellikle de kentsel bir mekân olan meydan, parçası olduğu kentle fiziksel, sosyal, kültürel, tarihsel bağlamda bir bütün oluşturmuştur (Ölmez Kalender ve Demiroğlu, 2011). Ancak; günümüzde teknolojik gelişmeler, değişen ve dönüşen yaşam standartları ve hızlı nüfus artışı ile birlikte büyüyen kentler için meydanlar; kavşak noktaları veya otopark alanlarına dönüşmüşlerdir (Kır, 2009; Özer ve Ayten, 2005). Taşçı'nın (2014) da belirttiği gibi; antik Yunan kentlerinde içinde çeşitli toplumsal konuların tartışıldığı agoralar, daha sade ve işlevsel yaşam tarzını, Ortaçağda düzgün geometrik formlara sahip olmayan ancak birçok heykelin sergilendiği meydanlar, insanı ön plana çıkaran ve sanatsal yaşam tarzını, 
Rönesans'ta denge unsurunun egemen olduğu meydanlar, şekilciliği temel alan yaşam tarzını, barok dönemde hareketliliğin görüldüğü meydanlar, süslü ve gösterişli yaşam tarzını, modern dönemde meydanlar ise kent dokusu içinde sıkışıp kalmış, araç odaklı daha mekanik bir yaşam tarzını ortaya yansımışlardır. Bu noktada meydanlar, zaman içerisinde işlev ve form açısından farklılıklar göstererek mekânsal nitelikleri ve karakteristik özellikleri ile görsel yönden de farklı tasarımlarla etkin birer karakter kazanmışlardır (Altınçekiç, 2000; Sancar ve Acar, 2016). Dolayısıyla da imaj, kimlik ve anlam bütününde ortaya çıkan dönüşümlerle birlikte meydanlar üzerinde fiziksel, görsel ve sosyal anlamda etkileşimler gözlemlenmiştir. Bu durumda meydanların içinde bulunduğu çevrenin görsel kalitesinin kullanıcı tarafından algılanış şekli de oldukça önemlidir. Aksi takdirde, kullanıcı algısı zayıfladıkça, insan ile çevresi arasındaki ilişki giderek eksilerek, tercih edilmemesine neden olur. Bu kapsamda, makalede, tarihte üç büyük imparatorluğa başkentlik ve çeşitli kültürlere ev sahipliği yapmış yedi tepe üzerine kurulmuş İstanbul İli için önemli bir tarihi birikime sahip Taksim meydanı ve yakın çevresinin geçmiş ve günümüz durumunun görsel peyzaj kalitesine ilişkin değişimi irdelenmiştir. Bu doğrultuda çalışmada; alana ilişkin eski ve yeni kent görünümleri açısından görsel peyzaja ilişkin algısal farklılıklar saptanarak, aşağıdaki sorulara cevap aranmıştır;

- Taksim meydanı ve yakın çevresinin geçmiş ve günümüz görünümleri arasında hangisi tercih edilmektedir?

- Taksim meydanı ve yakın çevresinin geçmiş ve günümüz görünümleri açısından görsel yönden çekicilik gösteren alanlar nelerdir?

\section{MATERYAL ve YÖNTEM}

Araştırmanın ana materyalini İstanbul'un Beyoğlu ilçesinde yer alan Taksim Meydanı ve yakın çevresi oluşturmaktadır. Seçilen alan yaklaşık olarak $210.000 \mathrm{~m}^{2}$ dir. Araştırma alanı; İstiklal Caddesi, Abdülhak Hamit Caddesi ve Yedikuyular Caddesi üzerinden Talimhane bölgesi, Gezi parkı ile Mete Caddesi üzerinden ise Atatürk Kültür Merkezi, Taksim Meydanı'nı kapsayarak İsmet İnönü Caddesi, Dünya S. Sokağı, Osmanlı Sokağı'nın bir kısmı ile Sıraselviler Caddesi'ne bağlanmaktadır.

Taksim Meydanı, İstanbul ilinde Beyoğlu İlçesi Gümüssuyu mahallesi sınırları içerisinde; İstiklal Caddesi, Sıraselviler Caddesi, Gümüşsuyu Caddesi ve Tarlabaşı Bulvarının kesişim noktasında bulunmakta olup, 72.410 m2 lik bir yüzölçümüne sahiptir (Şekil 1).

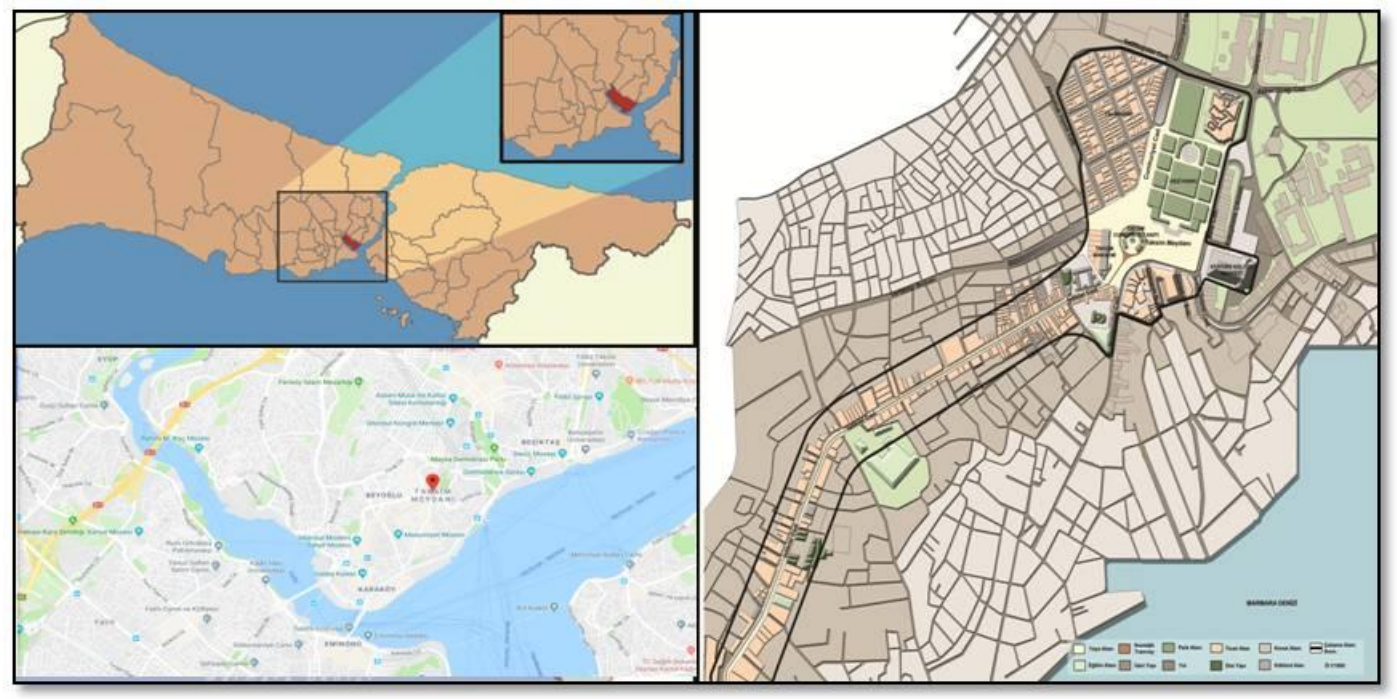

Şekil 1. Araştırma alanının konumu

Araştırma alanı olarak Taksim Meydanı ve yakın çevresinin seçilmesinde; İstanbul kent kimliğinin simgesi niteliğinde olması,kentin önemli ulaşım bağlantılarını üzerinde barındırması,tarihi anıtsal yapı ve geleneksel mimari dokuyu bulundurması, ticari mekanlara sahip olması, İstanbul kenti için bir landmark niteliği taşıması ve yoğun bir kullanım talebine sahip olması etkili olmuştur. Alan ve yapı çevresine ilişkin yapı-fonksiyon durumları Şekil 2. de verilmiştir. 


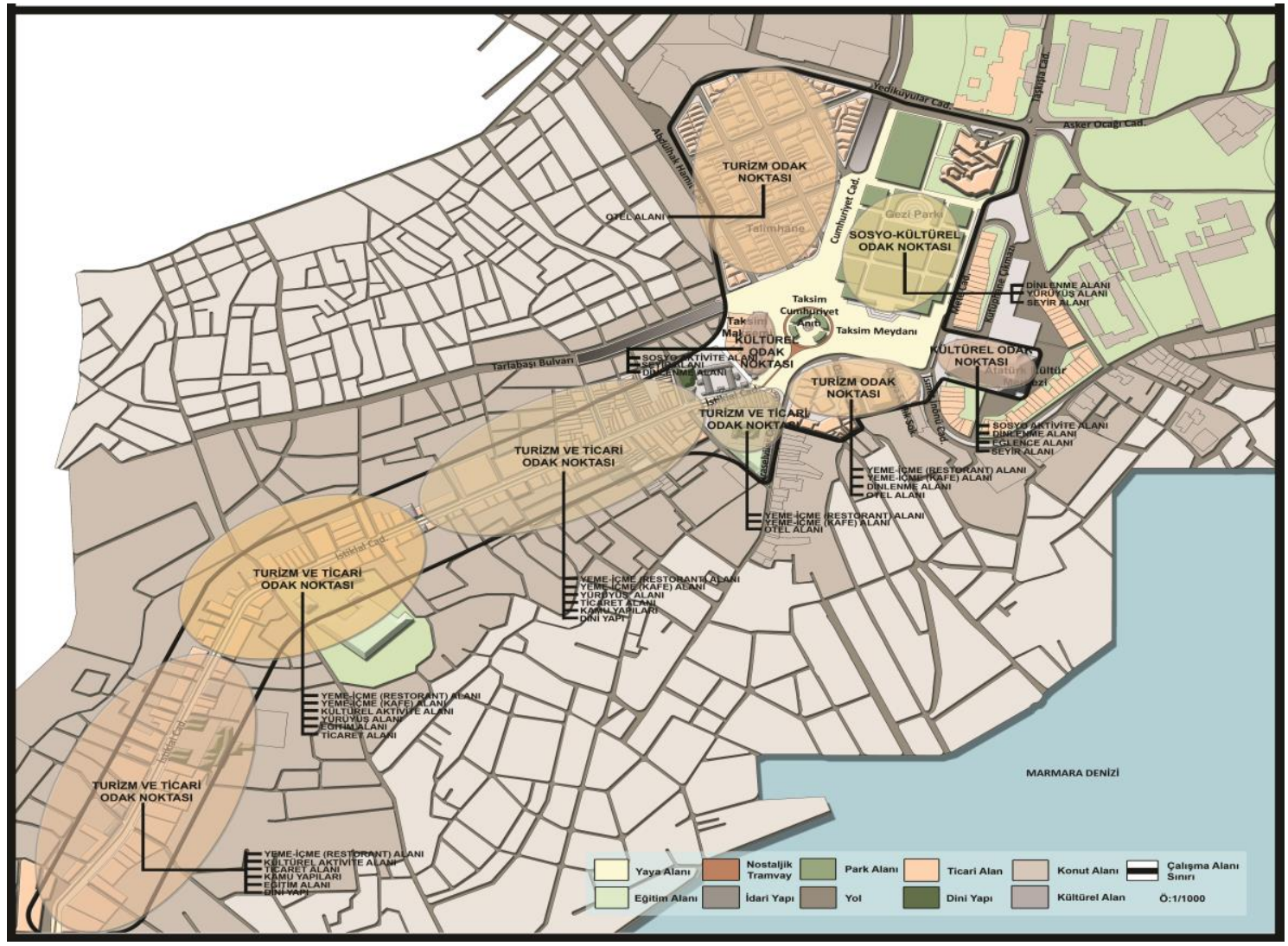

Şekil 2. Taksim Meydanı ve yakın çevresi yapı fonksiyon durumu

Araştırmada; ikincil veri olarak; araştırma konusu, kapsamı hakkında incelenen ulusal ve uluslararası yayınlar, kitap, dergi, makaleler ve tezlerden elde edilen verilerden,geçmiş dönemlere ait planlar ve İstanbul Metropoliten Plan Bürosu tarafından yapılan 1/1000 ölçekli imar plan ve raporlarından,alanda yapılan gözlemler ve çekilen fotoğraflardan, görsel peyzaj analizi aşamasında yapılan uzman anketlerinden yararlanılmıştır. Anketlerin değerlendirilmesi için SPSS istatistik programı kullanılmıştır.

Çalışma kapsamında; görsel peyzaj analizi yöntemi kullanılmıştır. Bu kapsamda birçok fotoğraf çekilmiştir. Bu fotoğraflardan görsel peyzaj kalitesinin belirlenmesine esas olabileceği düşünülen Taksim Meydanı ve yakın çevresinde yer alan kentsel kimlik açısından önem teşkil eden Taksim Meydanı, Taksim Maksemi, İstiklal Caddesi, Cumhuriyet Caddesi, Gezi Parkı, Atatürk Kültür Merkezi, The Marmara Oteli'ne ait 7 şer adet fotoğraftan oluşan geçmiş ve günümüz (2016 yılı) görüntüleri kullanılmıştır (Şekil 3).

Fotoğrafların seçiminde; geniş görüş imkanı sunan ve geçmişten günümüze kadarki dönemlerde kent kimliğine önemli katkıları olan mekanlar ve görüntüler etken olmuştur. Seçilen 7 şer adet fotoğrafın geçmiş ve günümüz görüntüleri, alanı iyi tanıyan mimar, şehir plancısı ve peyzaj mimarlarından oluşan 12 kişilik uzman grubu tarafından değerlendirilmiştir. Fotoğraflara dayalı olarak geçmiş ve günümüz kullanımlarına yönelik yapılan görsel peyzaj analizine yönelik değerlendirme parametrelerinin belirlenmesinde; Müderrisoğlu \& Eroğlu 2006; Özhancı \& Yılmaz 2011; Kıroğlu 2007; Kuğu Tüfekçioğlu 2008; Altınçekiç vd. 2014; Kiper vd. 2016'nın yapmış oldukları çalışmalardan yararlanıımıştır. Uzman grubunun geçmiş ve günümüz görüntülerini içeren 7 şer adet fotoğrafı, 5 ana ve 18 alt başlıktan oluşan parametreler açısından (Tablo 1) 5'li Likert Skalası (1 en düşük 5 en yüksek değeri ifade etmektedir) ile değerlendirmeleri sağlanmıştır. 


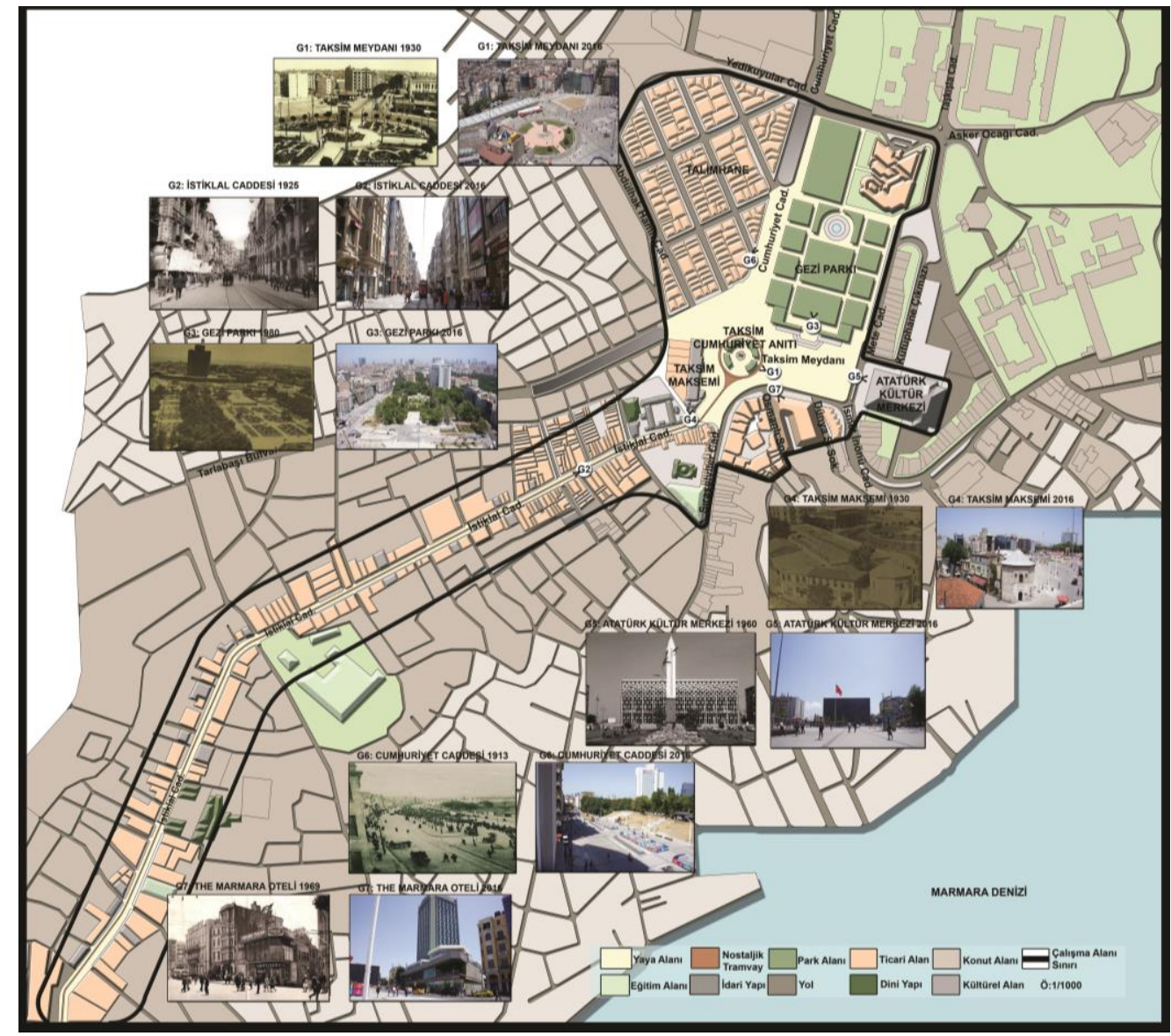

Şekil 3. Görsel peyzaj analizinde kullanılan fotoğraflar ve çekim noktaları

Saptanan verilerin değerlendirme sonuçlarının yorumlanmasında ise (Özkan vd., 2015) kent görünümlerinde görsel tercih değerlendirmesi çalışmasından faydalanılmıştır. Elde edilen bilgiler doğrultusunda geçmiş ve günümüz arasında kıyaslamalar yapılmıştır.

Uzman grubunun değerlendirme ölçütlerine vermiş oldukları puanlamaların yüzdelik ortalamaları istatistiksel analizlerle ortaya konmuştur. Yüzdelik değerler her bir fotoğrafta kullanılan parametre için ayrı ayrı hesaplanarak, uzman grubunun beğeni dereceleri analiz edilmiştir. Analizlerde ilk olarak anket çalışmasında kullanılan eski ve mevcut görüntülere ilişkin 7 adet fotoğraf ayrı ayrı olarak kendi içinde en yüksek puan alan kriter ve en düşük puan alan kriter olarak değerlendirilmiştir. Daha sonra her bir fotoğrafın en yüksek (5) kriterde ki yüzdeleri toplanmış ve toplam görüntü sayısına bölünmüştür. Bunun sonucunda en yüksek kriterdeki yüzde oranı 360 üzeri alanlar üstün nitelikli, 360-240 puan üzerinde olan görüntüler iyi görüntü, 240-120 arasında olanlar orta, 120 altında olanlar ise kötü görüntü olarak kabul edilmiştir. 
Tablo 1.Görsel Peyzaj Analizi aşamasında kullanılan parametreler(Müderrisoğlu \& Eroğlu, 2006; Özhancı \& Yılmaz, 2011; Kıroğlu, 2007; Kuğu Tüfekçioğlu, 2008; Altınçekiç vd., 2014; Kiper vd., 2016)

\begin{tabular}{|c|c|}
\hline $\begin{array}{c}\text { Ana } \\
\text { Parametreler }\end{array}$ & Alt Parametreler \\
\hline \multirow{3}{*}{ Uyum } & Fotoğrafın çevresiyle uyumu \\
\hline & $\begin{array}{c}\text { Topografya, bitkisel öğeler ve yapısal öğelerin birbiriyle } \\
\text { uyumu }\end{array}$ \\
\hline & Alanın mevcut öğeleriyle kimlik (karakter) kazanması \\
\hline \multirow{6}{*}{ Okunabilirlik } & Peyzajın algılanabilirliği \\
\hline & Algıya açık yönlenme \\
\hline & Algıya kapalılık (sınırlılık) \\
\hline & Ayırt edici öğelerin varlığı \\
\hline & Alanda bulunan özgün öğelerin varlığı \\
\hline & Bakımlı temiz alan varlığı \\
\hline \multirow{4}{*}{$\begin{array}{l}\text { Manzara } \\
\text { Güzelliği }\end{array}$} & Görüntünün açıklığı (seçilebilirlik) \\
\hline & Görülebilen alanın büyüklüğü \\
\hline & Görüntünün derinliği \\
\hline & Görüntünün netliği (engelleyen unsurların olmaması) \\
\hline \multirow{2}{*}{ Tarihsellik } & Tarihi öğelerin varlığı \\
\hline & Tarihi öğelerin korunmuşluğu \\
\hline \multirow{3}{*}{ Konfor } & İnsan ölçüsüne uygunluk \\
\hline & Kent mobilyası varlığı ve imaj etkisi \\
\hline & Renk, malzeme, doku açısından hoşnut olma durumu \\
\hline
\end{tabular}

\section{BULGULAR}

Uzman grubunun geçmiş ve günümüz görüntülerine ait her bir fotoğrafa ilişkin değerlendirme ölçütlerine vermiş oldukları puanlamaların yüzdelik ortalamaları istatistiksel analizlerle ortaya konularak tablolar şeklinde verilmiştir (Tablo 2, Tablo 3, Tablo 4, Tablo 5, Tablo 6, Tablo 7, Tablo 8). Tablolarda uzman grubunun verdikleri puanlara göre görüntü üzerinde en düşük ve en yüksek puan alan ölçütler saptanarak genel değerlendirme yapılmıştır. 
Tablo 2.Görüntü 1'e ilişkin değerlendirme sonuçları

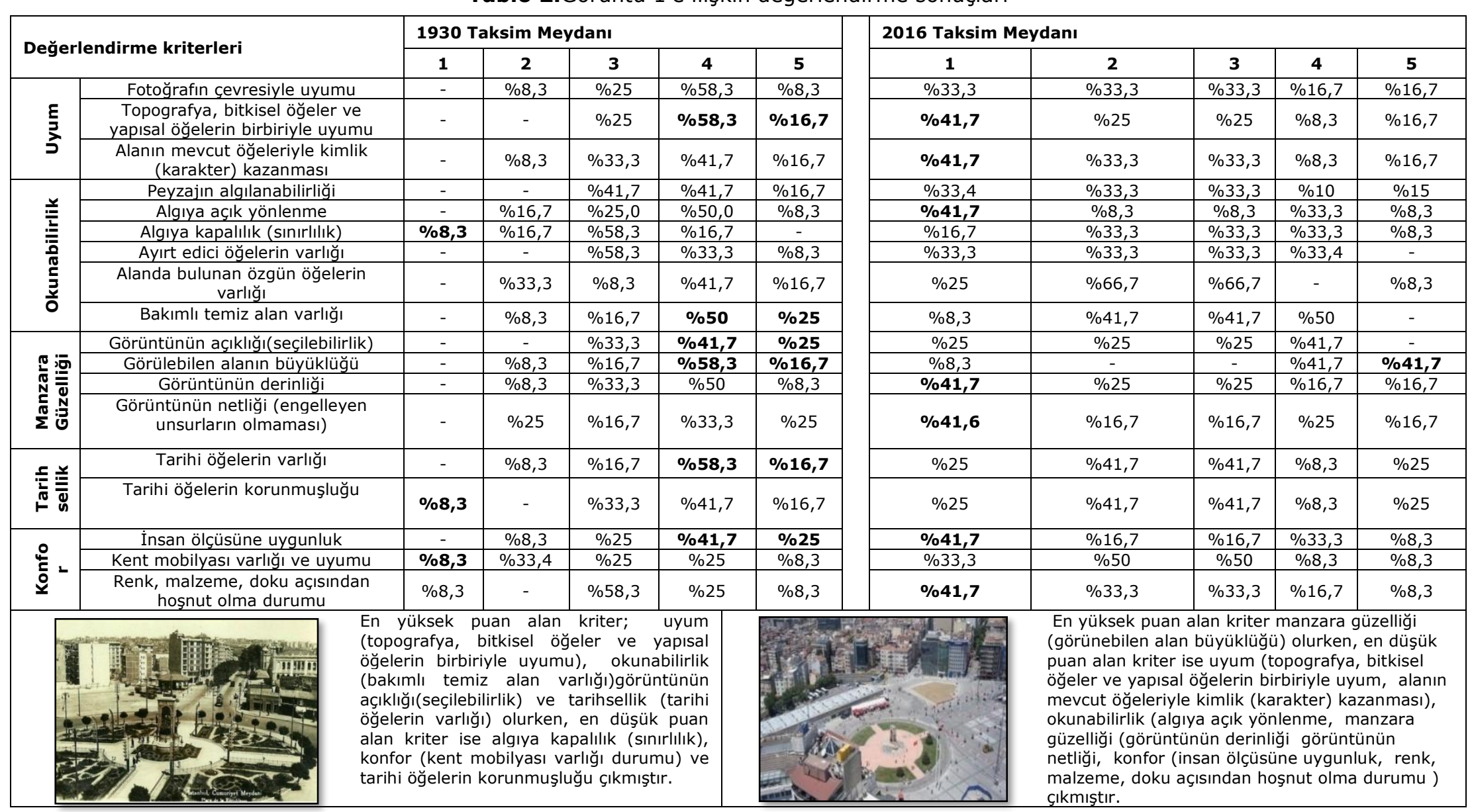


Tablo 3.Görüntü 2'ye ilişskin değerlendirme sonuçları

\begin{tabular}{|c|c|c|c|c|c|c|c|c|c|c|c|}
\hline \multirow{2}{*}{\multicolumn{2}{|c|}{ Değerlendirme kriterleri }} & \multicolumn{5}{|c|}{1925 İstiklal Caddesi } & \multicolumn{5}{|c|}{2016 İstiklal Caddesi } \\
\hline & & 1 & 2 & 3 & 4 & 5 & 1 & 2 & 3 & 4 & 5 \\
\hline \multirow{3}{*}{ 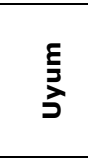 } & Fotoğrafın çevresiyle uyumu & - & - & $\% 16,7$ & $\% 41,7$ & $\% 41,7$ & $\% 33,3$ & $\% 33,3$ & $\% 33,3$ & $\% 16,7$ & $\% 16,7$ \\
\hline & $\begin{array}{l}\text { Topografya, bitkisel öğeler ve } \\
\text { yapısal öğelerin birbiriyle uyumu }\end{array}$ & $\% 8,3$ & $\% 16,7$ & $\% 25$ & $\% 25$ & $\% 25$ & $\% 41,7$ & $\% 25$ & $\% 25$ & $\% 8,3$ & $\% 16,7$ \\
\hline & $\begin{array}{l}\text { Alanın mevcut öğeleriyle kimlik } \\
\text { (karakter) kazanması }\end{array}$ & - & - & $\% 25$ & $\% 33,3$ & $\% 41,7$ & $\% 41,7$ & $\% 33,3$ & $\% 33,3$ & $\% 8,3$ & $\% 16,7$ \\
\hline \multirow{6}{*}{ 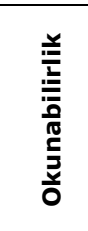 } & Peyzajın algılanabilirliği & - & - & $\% 41,7$ & $\% 33,3$ & $\% 25$ & $\% 33,4$ & $\% 33,3$ & $\% 33,3$ & $\% 10$ & $\% 15$ \\
\hline & Algıya açık yönlenme & - & $\% 25$ & $\% 8,3$ & $\% 41,7$ & $\% 25$ & $\% 41,7$ & $\% 8,3$ & $\% 8,3$ & $\% 33,3$ & $\% 8,3$ \\
\hline & Algıya kapalılık (sınırlılık) & $\% 16,7$ & - & $\% 25$ & $\% 58,3$ & - & $\% 16,7$ & $\% 33,3$ & $\% 33,3$ & $\% 33,3$ & $\% 8,3$ \\
\hline & Ayırt edici öğelerin varlığı & - & $\% 8,3$ & $\% 41,7$ & $\% 33,3$ & $\% 16,7$ & $\% 33,3$ & $\% 33,3$ & $\% 33,3$ & $\% 33,4$ & - \\
\hline & $\begin{array}{c}\text { Alanda bulunan özgün öğelerin } \\
\text { varlığı }\end{array}$ & - & $\% 8,3$ & $\% 25$ & $\% 33,3$ & $\% 33,3$ & $\% 25$ & $\% 66,7$ & $\% 66,7$ & - & $\% 8,3$ \\
\hline & Bakımlı temiz alan varlığı & - & $\% 8,3$ & $\% 16,7$ & $\% 41,7$ & $\% 33,3$ & $\% 8,3$ & $\% 41,7$ & $\% 41,7$ & $\% 50$ & - \\
\hline \multirow{4}{*}{ 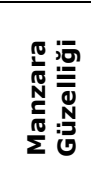 } & Görüntünün açıklı̆ı̆(seçilebilirlik) & - & - & $\% 41,7$ & $\% 25$ & $\% 33,3$ & $\% 25$ & $\% 25$ & $\% 25$ & $\% 41,7$ & - \\
\hline & Görülebilen alanın büyüklüğü & - & - & $\% 16,7$ & $\% 66,7$ & $\% 16,7$ & $\% 8,3$ & - & - & $\% 41,7$ & $\% 41,7$ \\
\hline & Görüntünün derinliği & - & - & $\% 25$ & $\% 33,3$ & $\% 41,7$ & $\% 41,7$ & $\% 25$ & $\% 25$ & $\% 16,7$ & $\% 16,7$ \\
\hline & $\begin{array}{l}\text { Görüntünün netliği (engelleyen } \\
\text { unsurların olmaması) }\end{array}$ & - & $\% 16,7$ & $\% 25$ & $\% 33,3$ & $\% 25$ & $\% 41,6$ & $\% 16,7$ & $\% 16,7$ & $\% 25$ & $\% 16,7$ \\
\hline \multirow{2}{*}{ 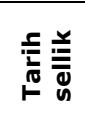 } & Tarihi öğelerin varlığı & - & $\% 33,3$ & $\% 8,3$ & $\% 16,7$ & $\% 41,7$ & $\% 25$ & $\% 41,7$ & $\% 41,7$ & $\% 8,3$ & $\% 25$ \\
\hline & Tarihi öğelerin korunmuşluğu & - & $\% 25$ & $\% 8,3$ & $\% 25$ & $\% 41,7$ & $\% 25$ & $\% 41,7$ & $\% 41,7$ & $\% 8,3$ & $\% 25$ \\
\hline \multirow{3}{*}{ 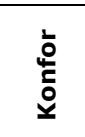 } & İnsan ölçüsüne uygunluk & - & $\% 8,3$ & $\% 25$ & $\% 41,7$ & $\% 25$ & $\% 41,7$ & $\% 16,7$ & $\% 16,7$ & $\% 33,3$ & $\% 8,3$ \\
\hline & Kent mobilyası varlığı ve uyumu & - & $\% 25$ & $\% 16,7$ & $\% 50$ & $\% 8,3$ & $\% 33,3$ & $\% 50$ & $\% 50$ & $\% 8,3$ & $\% 8,3$ \\
\hline & $\begin{array}{l}\text { Renk, malzeme, doku açısından } \\
\text { hoşnut olma durumu }\end{array}$ & - & $\% 16,7$ & $\% 33,3$ & $\% 33,3$ & $\% 16,7$ & $\% 41,7$ & $\% 33,3$ & $\% 33,3$ & $\% 16,7$ & $\% 8,3$ \\
\hline & $>$ & \multicolumn{4}{|c|}{$\begin{array}{l}\text { En yüksek puan alan kriter uyum } \\
\text { (fotoğrafın cevresiyle uyumu,alanın } \\
\text { mevcut öğeleriyle kimlik (karakter) } \\
\text { kazanması), okunabilirlik (bakımlı } \\
\text { temiz alan varlığı),manzara güzelliği } \\
\text { (görünebilen alanın büyüklüğü, } \\
\text { görüntünün derinliği), tarihsellik } \\
\text { (tarihi öğelerin varlığı ve tarihi } \\
\text { öğelerin korunmuşluğu) olurken, en } \\
\text { düşük puan alan kriter ise okunabilirlik } \\
\text { (algıya kapalılık) çıkmıştır }\end{array}$} & & & & \multicolumn{3}{|c|}{$\begin{array}{l}\text { En yüksek puan alan kriter fotoğrafın } \\
\text { çevresiyle uyumu, okunabilirlik } \\
\text { (algıya kapalılık, sınırlılık)olurken, er } \\
\text { düşük puan alan kriter ise tarihsellik } \\
\text { (tarihi öğelerin varlığı) çıkmışır. }\end{array}$} \\
\hline
\end{tabular}


Tablo 4.Görüntü 3'e ilişkin değerlendirme sonuçları

\begin{tabular}{|c|c|c|c|c|c|c|c|c|c|c|c|}
\hline \multirow{2}{*}{\multicolumn{2}{|c|}{ Değerlendirme kriterleri }} & \multicolumn{5}{|c|}{1980 Gezi Parkı } & \multicolumn{5}{|c|}{2016 Gezi Parkı } \\
\hline & & 1 & 2 & 3 & 4 & 5 & 1 & 2 & 3 & 4 & 5 \\
\hline \multirow{3}{*}{$\frac{\xi}{3}$} & Fotoğrafın çevresiyle uyumu & - & $\% 8,3$ & $\% 8,3$ & $\% 58,3$ & $\% 25$ & - & $\% 8,3$ & $\% 58,3$ & $\% 33,3$ & - \\
\hline & $\begin{array}{c}\text { Topografya, bitkisel öğeler ve } \\
\text { yapısal öğelerin birbiriyle uyumu }\end{array}$ & - & - & $\% 16,7$ & $\% 66,7$ & $\% 16,7$ & $\% 16,7$ & $\% 25$ & $\% 50$ & - & $\% 8,3$ \\
\hline & $\begin{array}{c}\text { Alanın mevcut öğeleriyle kimlik } \\
\text { (karakter) kazanması }\end{array}$ & - & $\% 8,3$ & $\% 16,7$ & 50 & 25 & - & $\% 41,7$ & $\% 41,7$ & - & $\% 16,7$ \\
\hline \multirow{6}{*}{ 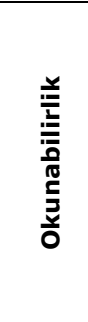 } & Peyzajın algılanabilirliği & - & - & $\% 16,7$ & $\% 50$ & $\% 33,3$ & $\% 8,3$ & $\% 8,3$ & $\% 66,7$ & - & $\% 16,7$ \\
\hline & Algıya açık yönlenme & - & - & $\% 8,3$ & $\% 58,3$ & $\% 33,3$ & - & $\% 25$ & $\% 58,3$ & - & $\% 16,7$ \\
\hline & Algıya kapalılık (sınırlılık) & - & $\% 25$ & $\% 33,3$ & $\% 33,3$ & $\% 8,3$ & - & $\% 25$ & $\% 25$ & $\% 16,7$ & $\% 33,3$ \\
\hline & Ayırt edici öğelerin varlığı & - & - & $\% 33,3$ & $\% 50$ & $\% 16,7$ & - & $\% 41,7$ & $\% 50$ & - & $\% 8,3$ \\
\hline & $\begin{array}{c}\text { Alanda bulunan özgün öğelerin } \\
\text { varlığı }\end{array}$ & - & - & $\% 41,7$ & $\% 50$ & $\% 8,3$ & $\% 8,3$ & $\% 41,7$ & $\% 25$ & - & $\% 25$ \\
\hline & Bakımlı temiz alan varlığı & - & $\% 16,7$ & $\% 16,7$ & $\% 33,3$ & $\% 33,3$ & - & $\% 25$ & $\% 41,7$ & - & $\% 33,3$ \\
\hline \multirow{4}{*}{ 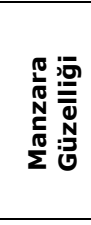 } & Görüntünün açıklığı(seçilebilirlik) & - & \%16,7 & $\% 8,3$ & $\% 41,7$ & $\% 33,3$ & - & $\% 16,7$ & $\% 58,3$ & - & $\% 25$ \\
\hline & Görülebilen alanın büyüklüğü & - & $\% 8,3$ & $\% 8,3$ & $\% 33,3$ & $\% 50$ & - & $\% 25$ & $\% 66,7$ & - & $\% 8,3$ \\
\hline & Görüntünün derinliği & - & - & $\% 33,3$ & $\% 25$ & $\% 41,7$ & $\% 8,3$ & $\% 25$ & $\% 58,3$ & - & $\% 8,3$ \\
\hline & $\begin{array}{c}\text { Görüntünün netliği (engelleyen } \\
\text { unsurların olmaması) }\end{array}$ & - & - & $\% 41,7$ & $\% 25$ & $\% 33,3$ & $\% 8,3$ & $\% 41,7$ & $\% 25$ & - & $\% 25$ \\
\hline \multirow{2}{*}{ 帛 } & Tarihi öğelerin varlığı & - & $\% 25$ & $\% 33,3$ & $\% 33,3$ & $\% 8,3$ & $\% 25$ & $\% 25$ & $\% 25$ & - & $\% 25$ \\
\hline & Tarihi öğelerin korunmuşluğu & - & $\% 8,3$ & $\% 25$ & $\% 58,3$ & $\% 8,3$ & $\% 16,7$ & $\% 50$ & $\% 16,7$ & - & $\% 16,7$ \\
\hline \multirow{3}{*}{$\begin{array}{l}\grave{0} \\
\grave{c} \\
\grave{c}\end{array}$} & İnsan ölçüsüne uygunluk & - & $\% 8,3$ & $\% 33,3$ & $\% 50$ & $\% 8,3$ & - & $\% 25$ & $\% 33,3$ & $\% 8,3$ & $\% 16,7$ \\
\hline & Kent mobilyası varlığı ve uyumu & - & $\% 8,3$ & $\% 41,7$ & $\% 33,3$ & $\% 16,7$ & $\% 16,7$ & $\% 41,7$ & $\% 16,7$ & - & $\% 25$ \\
\hline & $\begin{array}{c}\text { Renk, malzeme, doku açısından } \\
\text { hoşnut olma durumu } \\
\end{array}$ & - & $\% 16,7$ & $\% 25$ & $\% 41,7$ & $\% 16,7$ & - & $\% 8,3$ & $\% 58,3$ & - & $\% 33,3$ \\
\hline 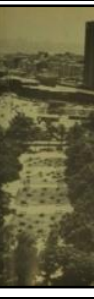 & \multicolumn{5}{|c|}{$\begin{array}{l}\text { En yüksek puan alan kriter manzara güzelliği } \\
\text { (görüllebilen alanın büyüklüğğü ve görüntünün } \\
\text { derinliği) olurken, en düşük puan alan kriter ise } \\
\text { çımamıştır }\end{array}$} & $\lim ^{2}$ & & \multicolumn{4}{|c|}{$\begin{array}{l}\text { En yüksek puan alan kriter; okunabilirlik } \\
\text { (algıya kapalılık, bakımlı temiz alan varlığı), } \\
\text { konfor (renk, malzeme, doku açısından } \\
\text { hoşnut olma durumu ) etkisi olurken, en düşük } \\
\text { puan alan kriter ise tarihsellik (tarihi öğelerin } \\
\text { varlığı) çıkmışıı. }\end{array}$} \\
\hline
\end{tabular}


Tablo 5.Görüntü 4'e ilişkin değerlendirme sonuçları

\begin{tabular}{|c|c|c|c|c|c|c|c|c|c|c|c|}
\hline \multirow{2}{*}{\multicolumn{2}{|c|}{ Değerlendirme kriterleri }} & \multicolumn{5}{|c|}{ 1930Taksim Maksemi } & \multicolumn{5}{|c|}{2016 Taksim Maksemi } \\
\hline & & \multirow{2}{*}{$\begin{array}{l}1 \\
-\end{array}$} & \multirow{2}{*}{$\begin{array}{l}2 \\
-\end{array}$} & \multirow{2}{*}{$\begin{array}{c}\mathbf{3} \\
\% 50\end{array}$} & \multirow{2}{*}{\begin{tabular}{c|}
$\mathbf{4}$ \\
$\% 33,3$
\end{tabular}} & \multirow{2}{*}{$\begin{array}{c}\mathbf{5} \\
\% 16,7\end{array}$} & \multirow{2}{*}{$\begin{array}{l}1 \\
-\end{array}$} & \multirow{2}{*}{$\frac{2}{\% 25}$} & \multirow{2}{*}{$\begin{array}{c}\mathbf{3} \\
\% 33,3\end{array}$} & \multirow{2}{*}{$\begin{array}{c}4 \\
\% 25\end{array}$} & \multirow{2}{*}{$\begin{array}{c}\mathbf{5} \\
\% 16,7\end{array}$} \\
\hline \multirow{3}{*}{$\sum_{3}^{\varepsilon}$} & Fotoğrafın çevresiyle uyumu & & & & & & & & & & \\
\hline & $\begin{array}{c}\text { Topografya, bitkisel öğeler ve } \\
\text { yapısal öğelerin birbiriyle uyumu }\end{array}$ & - & - & $\% 41,7$ & $\% 58,3$ & - & - & $\% 41,7$ & $\% 33,3$ & $\% 25$ & - \\
\hline & $\begin{array}{c}\text { Alanın mevcut öğeleriyle kimlik } \\
\text { (karakter) kazanması }\end{array}$ & - & $\% 8,3$ & - & $\% 75$ & $\% 16,7$ & $\% 9,1$ & $\% 18,9$ & $\% 45,5$ & $\% 18,2$ & $\% 8,3$ \\
\hline \multirow{6}{*}{ 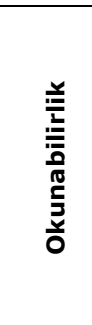 } & Peyzajın algılanabilirliği & - & $\% 25$ & $\% 33,3$ & $\% 33,3$ & $\% 8,3$ & - & $\% 33,3$ & $\% 41,7$ & $\% 25$ & $\% 16,7$ \\
\hline & Algıya açık yönlenme & - & $\% 25$ & $\% 33,3$ & $\% 25$ & $\% 16,7$ & $\% 8,3$ & $\% 41,7$ & $\% 41,7$ & $\% 8,3$ & - \\
\hline & Algıya kapalılık (sınırlıık) & - & $\% 16,7$ & $\% 33,3$ & $\% 41,7$ & $\% 8,3$ & - & $\% 50$ & $\% 25$ & - & - \\
\hline & Ayırt edici öğelerin varlığı & - & $\% 16,7$ & $\% 16,7$ & $\% 33,3$ & $\% 33,3$ & $\% 8,3$ & $\% 16,7$ & $\% 31$ & $\% 16,7$ & $\% 25$ \\
\hline & $\begin{array}{c}\text { Alanda bulunan özgün öğelerin } \\
\text { varlığı }\end{array}$ & - & $\% 8,3$ & $\% 25$ & $\% 25$ & $\% 41,7$ & $\% 8,3$ & $\% 41,7$ & $\% 33,3$ & $\% 16,7$ & $\% 27,3$ \\
\hline & Bakımlı temiz alan varlığı & - & $\% 16,7$ & $\% 25$ & $\% 33,3$ & $\% 25$ & - & $\% 25$ & $\% 41,7$ & $\% 25$ & - \\
\hline \multirow{4}{*}{ 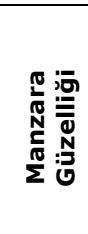 } & Görüntünün açıklığı(seçilebilirlik) & $\% 8,3$ & - & $\% 41,7$ & $\% 25$ & $\% 25$ & $\% 8,3$ & $\% 25$ & $\% 41,7$ & $\% 16,7$ & $\% 8,3$ \\
\hline & Görülebilen alanın büyüklüğü & - & $\% 41,7$ & $\% 16,7$ & $\% 33,3$ & $\% 8,3$ & - & $\% 33,3$ & $\% 50$ & $\% 16,7$ & $\% 8,3$ \\
\hline & Görüntünün derinliği & - & $\% 16,7$ & $\% 50$ & $\% 8,3$ & $\% 25$ & $\% 8,3$ & $\% 33,3$ & $\% 50$ & $\% 8,3$ & - \\
\hline & $\begin{array}{l}\text { Görüntünün netliği (engelleyen } \\
\text { unsurların olmaması) }\end{array}$ & - & - & $\% 50$ & $\% 25$ & $\% 25$ & $\% 8,3$ & $\% 58,3$ & $\% 16,7$ & $\% 8,3$ & - \\
\hline \multirow{2}{*}{ 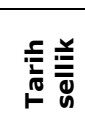 } & Tarihi öğelerin varlığı & - & $\% 8,3$ & $\% 25$ & $\% 16,7$ & $\% 50$ & $\% 8,3$ & $\% 16,7$ & $\% 25$ & $\% 33,3$ & $\% 8,3$ \\
\hline & Tarihi öğelerin korunmuşluğu & - & $\% 16,7$ & $\% 16,7$ & $\% 25$ & $\% 41,7$ & $\% 8,3$ & $\% 33,3$ & $\% 8,3$ & $\% 25$ & $\% 16,7$ \\
\hline \multirow{3}{*}{ 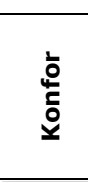 } & İnsan ölçüsüne uygunluk & - & $\% 8,3$ & $\% 8,3$ & $\% 50$ & $\% 33,3$ & - & $\% 33,3$ & $\% 33,3$ & $\% 25$ & $\% 8,3$ \\
\hline & Kent mobilyası varlığı ve uyumu & - & $\% 25$ & $\% 50$ & $\% 25$ & - & $\% 16,7$ & $\% 25$ & $\% 8,3$ & $\% 25$ & $\% 25$ \\
\hline & $\begin{array}{l}\text { Renk, malzeme, doku açısından } \\
\text { hoșnut olma durumu }\end{array}$ & $\% 16,7$ & - & $\% 33,3$ & $\% 25$ & $\% 25$ & $\% 8,3$ & $\% 8,4$ & $\% 33,3$ & $\% 25$ & $\% 25$ \\
\hline & $\begin{array}{l}\text { En yük } \\
\text { öğeler } \\
\text { puan a } \\
\text { doku } \\
\text { durum }\end{array}$ & $\begin{array}{l}\text { puan ala } \\
\text { varlığı) } \\
\text { kriter ise } \\
\text { açısında } \\
\text { çıkmıştır. }\end{array}$ & $\begin{array}{r}\text { kriter ta } \\
\text { tkisi olur } \\
\text { onfor ( } \mathbf{r} \\
\text { ho }\end{array}$ & $\begin{array}{l}\text { sellik ( } \\
\text { en, en } \\
\text { ik, malz } \\
\text { ut }\end{array}$ & $\begin{array}{l}\text { inhi } \\
\text { şük } \\
\text { ne, } \\
\text { ma }\end{array}$ & & & & $\begin{array}{l}\text { sek puan } \\
\text { buluna } \\
\text { urken, er } \\
\text { (kent m } \\
\end{array}$ & $\begin{array}{l}\text { kriter ok } \\
\text { gün öğel } \\
\text { uk puan } \\
\text { lası varlı }\end{array}$ & $\begin{array}{l}\text { jilirlik } \\
\text { varlığı ) } \\
\text { (riter ise } \\
\text { uyumu) }\end{array}$ \\
\hline
\end{tabular}


Tablo 6.Görüntü 5'e ilişkin değerlendirme sonuçları

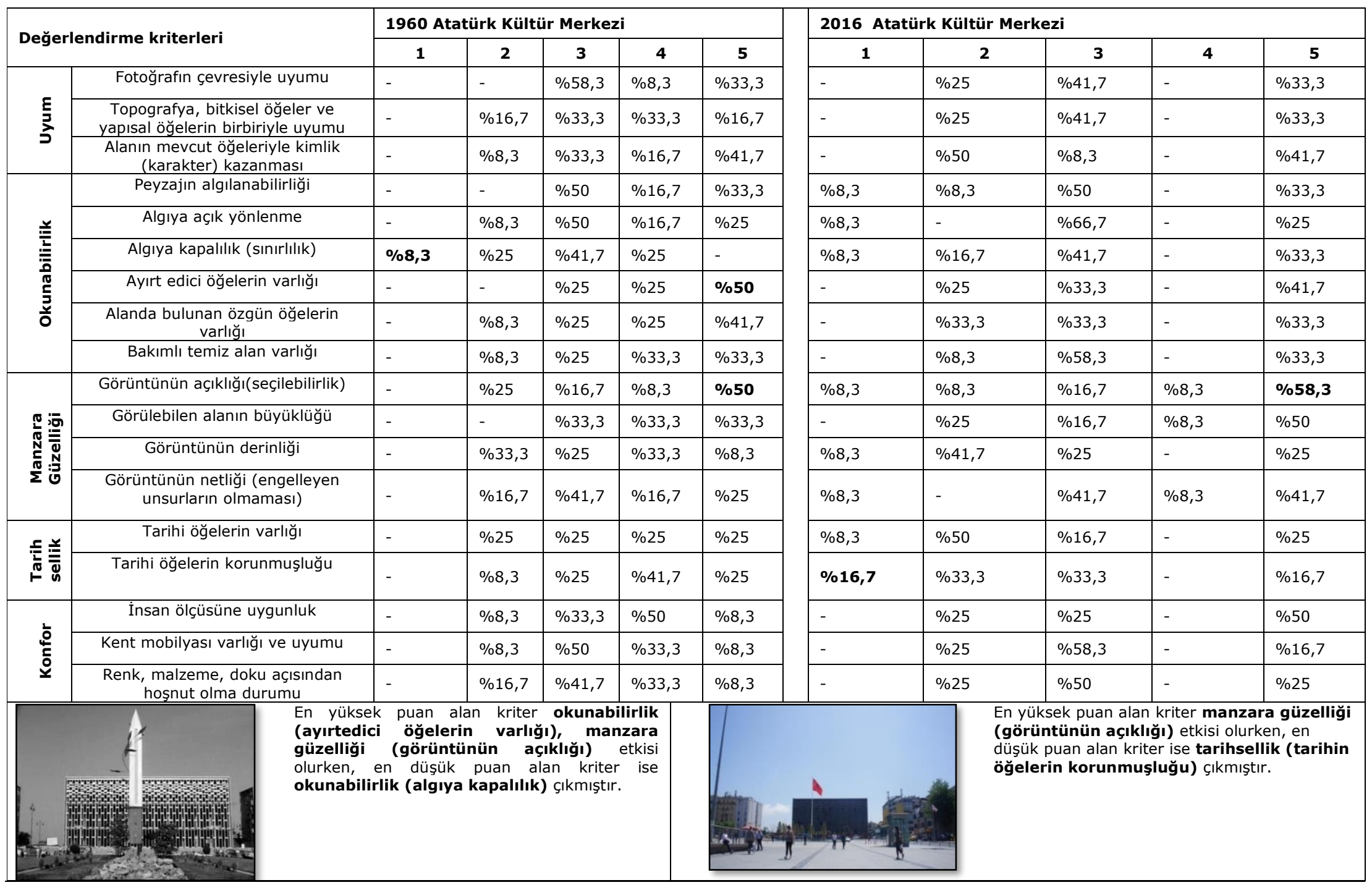


Tablo 7.Görüntü 6'ya ilişkin değerlendirme sonuçları

\begin{tabular}{|c|c|c|c|c|c|c|c|c|c|c|c|}
\hline \multirow{2}{*}{\multicolumn{2}{|c|}{ Değerlendirme kriterleri }} & \multicolumn{5}{|c|}{1913 Cumhuriyet Caddesi } & \multicolumn{5}{|c|}{2016 Cumhuriyet Caddesi } \\
\hline & & 1 & 2 & 3 & 4 & 5 & 1 & 2 & 3 & 4 & 5 \\
\hline \multirow{3}{*}{$\stackrel{\Sigma}{\Xi}$} & Fotoğrafın çevresiyle uyumu & - & - & $\% 16,7$ & $\% 66,7$ & $\% 16,7$ & $\% 8,3$ & $\% 16,7$ & $\% 50$ & $\% 8,3$ & $\% 16,7$ \\
\hline & $\begin{array}{c}\text { Topografya, bitkisel öğeler ve } \\
\text { yapısal öğelerin birbiriyle uyumu }\end{array}$ & - & - & $\% 25$ & $\% 50$ & $\% 25$ & $\% 8,3$ & $\% 41,7$ & $\% 25$ & - & $\% 25$ \\
\hline & $\begin{array}{c}\text { Alanın mevcut öğeleriyle kimlik } \\
\text { (karakter) kazanması }\end{array}$ & - & $\% 16,7$ & $\% 25$ & $\% 41,7$ & $\% 16,7$ & $\% 16,7$ & $\% 33,3$ & $\% 41,7$ & - & $\% 8,3$ \\
\hline \multirow{6}{*}{ 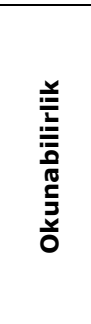 } & Peyzajın algılanabilirliği & - & - & $\% 8,3$ & $\% 58,3$ & $\% 33,3$ & - & $\% 33,3$ & $\% 33,3$ & $\% 8,3$ & $\% 25$ \\
\hline & Algıya açık yönlenme & - & $\% 16,7$ & $\% 8,3$ & $\% 41,7$ & $\% 33,3$ & - & $\% 16,7$ & $\% 66,7$ & $\% 8,3$ & $\% 8,3$ \\
\hline & Algıya kapalılık (sınırlılık) & $\% 8,3$ & $\% 25$ & $\% 41,7$ & $\% 16,7$ & $\% 8,3$ & $\% 33,3$ & $\% 16,7$ & $\% 41,7$ & - & $\% 8,3$ \\
\hline & Ayırt edici öğelerin varlığı & - & $\% 41,7$ & $\% 16,7$ & $\% 8,3$ & $\% 33,3$ & - & $\% 41,7$ & $\% 41,7$ & - & $\% 16,7$ \\
\hline & $\begin{array}{c}\text { Alanda bulunan özgün öğelerin } \\
\text { varlığı }\end{array}$ & - & $\% 50$ & $\% 8,3$ & $\% 16,7$ & $\% 25$ & $\% 8,3$ & $\% 33,3$ & $\% 25$ & - & $\% 33,3$ \\
\hline & Bakımlı temiz alan varlığı & - & $\% 16,7$ & $\% 33,3$ & $\% 8,3$ & $\% 41,7$ & - & $\% 8,3$ & $\% 25$ & $\% 16,7$ & $\% 50$ \\
\hline \multirow{4}{*}{ 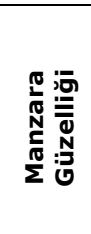 } & Görüntünün açıklı̆ı̆(seçilebilirlik) & - & $\% 16,7$ & $\% 16,7$ & $\% 33,3$ & $\% 33,3$ & $\% 8,4$ & $\% 8,3$ & $\% 33,3$ & $\% 8,3$ & $\% 41,7$ \\
\hline & Görülebilen alanın büyüklüğü & - & $\% 16,7$ & $\% 8,3$ & $\% 41,7$ & $\% 33,3$ & - & $\% 8,3$ & $\% 50$ & $\% 8,3$ & $\% 33,3$ \\
\hline & Görüntünün derinliği & $\% 8,3$ & $\% 25$ & $\% 16,7$ & $\% 16,7$ & $\% 33,3$ & - & $\% 50$ & $\% 33,3$ & - & $\% 16,7$ \\
\hline & $\begin{array}{l}\text { Görüntünün netliği (engelleyen } \\
\text { unsurların olmaması) }\end{array}$ & - & $\% 8,3$ & $\% 8,3$ & $\% 58,3$ & $\% 25$ & - & $\% 41,7$ & $\% 16,7$ & $\% 8,3$ & $\% 33,3$ \\
\hline \multirow{2}{*}{ 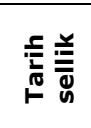 } & Tarihi öğelerin varlığı & $\% 8,3$ & $\% 25$ & $\% 25$ & $\% 8,3$ & $\% 33,3$ & $\% 33,3$ & $\% 41,7$ & $\% 25$ & - & - \\
\hline & Tarihi öğelerin korunmuşluğu & $\% 8,3$ & $\% 16,7$ & $\% 33,3$ & $\% 8,3$ & $\% 33,3$ & $\% 8,3$ & $\% 33,3$ & $\% 33,3$ & $\% 25$ & - \\
\hline \multirow{3}{*}{ 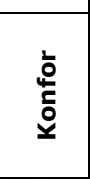 } & İnsan ölçüsüne uygunluk & - & - & $\% 25$ & $\% 41,7$ & $\% 33,3$ & - & $\% 41,7$ & $\% 25$ & $\% 8,3$ & $\% 25$ \\
\hline & Kent mobilyası varlığı ve uyumu & - & $\% 16,17$ & $\% 41,7$ & $\% 33,3$ & $\% 8,3$ & - & $\% 41,7$ & $\% 33,3$ & - & $\% 25$ \\
\hline & $\begin{array}{l}\text { Renk, malzeme, doku açısından } \\
\text { hoşnut olma durumu }\end{array}$ & - & $\% 25$ & $\% 33,3$ & $\% 33,3$ & $\% 8,3$ & $\% 8,3$ & $\% 25$ & $\% 50$ & - & $\% 16,7$ \\
\hline \multicolumn{6}{|c|}{ 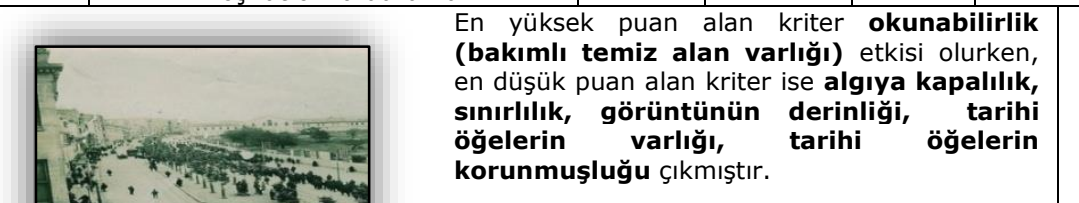 } & & & \multicolumn{4}{|c|}{$\begin{array}{l}\text { En yüksek puan alan kriter okunabilirlik (bakıml } \\
\text { temiz alan varlı̆̆ı) etkisi olurken, en düşük puan } \\
\text { alan kriter ise okunabilirlik (algıya kapalıık) ve } \\
\text { tarihsellik (tarihi öğelerin varlığı) çıkmıştır. }\end{array}$} \\
\hline
\end{tabular}


Tablo 8.Görüntü 7'ye ilişkin değerlendirme sonuçları

\begin{tabular}{|c|c|c|c|c|c|c|c|c|c|c|c|}
\hline \multirow{2}{*}{\multicolumn{2}{|c|}{ Değerlendirme kriterleri }} & \multicolumn{5}{|c|}{1969 The Marmara Oteli } & \multicolumn{5}{|c|}{2016 The Marmara Oteli } \\
\hline & & 1 & 2 & 3 & 4 & 5 & 1 & 2 & 3 & 4 & 5 \\
\hline \multirow{3}{*}{$\frac{\varepsilon}{3}$} & Fotoğrafın çevresiyle uyumu & - & - & $\% 58,3$ & $\% 33,3$ & $\% 8,3$ & $\% 8,3$ & $\% 33,3$ & $\% 25$ & $\% 16,7$ & $\% 16,7$ \\
\hline & $\begin{array}{l}\text { Topografya, bitkisel öğeler ve } \\
\text { yapısal öğelerin birbiriyle uyumu }\end{array}$ & - & $\% 16,7$ & $\% 50$ & $\% 25$ & $\% 8,3$ & $\% 16,7$ & $\% 41,7$ & $\% 33,3$ & $\% 8,3$ & - \\
\hline & $\begin{array}{c}\text { Alanın mevcut öğeleriyle kimlik } \\
\text { (karakter) kazanması }\end{array}$ & $\% 8,3$ & $\% 25$ & $\% 25$ & $\% 25$ & $\% 16,7$ & $\% 16,7$ & $\% 33,3$ & $\% 16,7$ & $\% 33,3$ & - \\
\hline \multirow{6}{*}{ 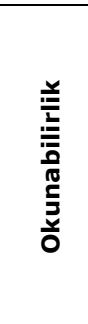 } & Peyzajın algılanabilirliği & - & $\% 41,7$ & $\% 33,3$ & $\% 16,7$ & $\% 8,3$ & $\% 8,3$ & $\% 33,3$ & $\% 33,3$ & $\% 25$ & - \\
\hline & Algıya açık yönlenme & - & $\% 27,3$ & $\% 36,4$ & $\% 27,3$ & $\% 9,1$ & $\% 16,7$ & $\% 16,7$ & $\% 33,3$ & $\% 25$ & $\% 8,3$ \\
\hline & Algıya kapalılık (sınırlılık) & - & $\% 33,3$ & $\% 41,7$ & $\% 16,7$ & $\% 8,3$ & - & $\% 33,3$ & $\% 33,3$ & $\% 25$ & $\% 8,3$ \\
\hline & Ayırt edici öğelerin varlığı & $\% 8,3$ & $\% 8,3$ & $\% 50$ & $\% 16,7$ & $\% 16,7$ & - & $\% 25$ & $\% 50$ & $\% 16,7$ & $\% 8,3$ \\
\hline & $\begin{array}{c}\text { Alanda bulunan özgün öğelerin } \\
\text { varlığı }\end{array}$ & $\% 8,3$ & $\% 33,3$ & $\% 8,3$ & $\% 33,3$ & $\% 16,7$ & $\% 8,3$ & $\% 41,7$ & $\% 25$ & $\% 16,7$ & $\% 8,3$ \\
\hline & Bakımlı temiz alan varlığı & - & $\% 16,7$ & $\% 41,7$ & $\% 16,7$ & $\% 25$ & - & - & $\% 41,7$ & $\% 58,3$ & - \\
\hline \multirow{4}{*}{ 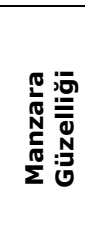 } & Görüntünün açıklığı(seçilebilirlik) & - & $\% 18,2$ & $\% 27,3$ & $\% 45,5$ & $\% 9,1$ & - & $\% 8,3$ & $\% 41,7$ & $\% 25$ & $\% 25$ \\
\hline & Görülebilen alanın büyüklüğü & - & $\% 33,3$ & $\% 33,3$ & $\% 33,3$ & - & $\% 8,3$ & $\% 16,7$ & $\% 33,3$ & $\% 33,3$ & $\% 8,3$ \\
\hline & Görüntünün derinliği & $\% 8,3$ & $\% 25$ & $\% 33,3$ & $\% 16,7$ & $\% 16,7$ & - & $\% 50$ & $\% 33,3$ & $\% 16,7$ & - \\
\hline & $\begin{array}{c}\text { Görüntünün netliği (engelleyen } \\
\text { unsurların olmaması) }\end{array}$ & $\% 8,3$ & - & $\% 58,3$ & $\% 25$ & $\% 8,3$ & - & $\% 41,7$ & $\% 16,7$ & $\% 16,7$ & $\% 25$ \\
\hline \multirow{2}{*}{ 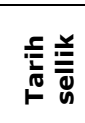 } & Tarihi öğelerin varlığı & $\% 16,7$ & $\% 16,7$ & $\% 25$ & $\% 25$ & $\% 16,7$ & $\% 16,7$ & $\% 58,3$ & $\% 16,7$ & $\% 8,3$ & - \\
\hline & Tarihi öğelerin korunmuşluğu & $\% 16,7$ & $\% 16,7$ & $\% 25$ & $\% 16,7$ & $\% 16,7$ & $\% 16,7$ & $\% 50$ & $\% 25$ & - & $\% 8,3$ \\
\hline \multirow{3}{*}{ 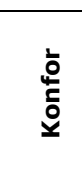 } & İnsan ölçüsüne uygunluk & - & - & $\% 33,3$ & $\% 50$ & $\% 16,7$ & $\% 8,3$ & $\% 25$ & $\% 33,3$ & $\% 33,3$ & - \\
\hline & \multirow{2}{*}{$\begin{array}{c}\text { Kent mobilyası varlığı ve uyumu } \\
\text { Renk, malzeme, doku açısından } \\
\text { hoşnut olma durumu } \\
\end{array}$} & - & $\% 8,3$ & $\% 58,3$ & $\% 25$ & $\% 8,3$ & $\% 8,3$ & $\% 33,3$ & $\% 33,3$ & $\% 25$ & - \\
\hline & & - & $\% 16,7$ & $\% 50$ & $\% 25$ & $\% 8,3$ & $\% 8,3$ & $\% 25$ & $\% 58,3$ & $\% 8,3$ & - \\
\hline$\frac{5}{2}$ & $\begin{array}{l}\text { In yük } \\
\text { (bakımlı } \\
\text { düsük pu } \\
\text { öğelerin } \\
\text { korunmı }\end{array}$ & \multicolumn{4}{|c|}{$\begin{array}{l}\text { Imu } \\
\text { En yüksek puan alan kriter okunabilirlik } \\
\text { (bakımlı temiz alan varlığı) etkisi olurken, en } \\
\text { düšük puan alan kriter ise tarihsellik (tarihi } \\
\text { ögelerin varlığı ve tarihi öğelerin } \\
\text { korunmuşluğu) çıkmıştır. }\end{array}$} & & & \multicolumn{4}{|c|}{$\begin{array}{l}\text { En yüksek puan alan kriter manzara güzelliği } \\
\text { (görüntünün açıklığı) etkisi olurken, en düšük } \\
\text { puan alan kriter ise uyum (topografya, bitkisel } \\
\text { öğeler ve yapısal öğelerin birbiriyle uyumu, alanın } \\
\text { mevcut öğeleriyle kimlik (karakter) kazanması), } \\
\text { okunabilirlik (algıłıa açık yönlenme), } \\
\text { tarihsellik (tarihi öğgelerin varığı, tarihi } \\
\text { öğelerin korunmuşluğu) çıkmışır }\end{array}$} \\
\hline
\end{tabular}




\section{SONUÇ}

Yapılan görsel peyzaj analizi sonucunda, öncelikle her bir ana ve alt parametre için uzman grubu tarafından geçmiş ve günümüz kullanımlarına ilişkin en yüksek puan alan görüntüler ana ve alt parametreler temelinde incelenerek çıkan sonuçlar Tablo 9. da karşılaştırılmıştır. Buna göre; geçmiş dönem görüntülerine ilişkin yapılan değerlendirmelere göre; uyum açısından İstiklal Caddesi, okunabilirlik açısından Gezi Parkı, Cumhuriyet Caddesi ve Atatürk Kültür Merkezi, manzara güzelliği açısından Gezi Parkı, tarihsellik ve konfor açısından Taksim Maksemi tercih edilmiştir. 2016 yılı görüntüleri açısından ise; Atatürk Kültür Merkezi uyum ve manzara güzelliği açısından, Gezi Parkı da okunabilirlik açısından en çok tercih edilen alan olarak değerlendirilmiştir.

Tablo 9. Parametre bazında en yüksek puan alan geçmiş ve günümüz görüntüleri

\begin{tabular}{|c|c|c|c|}
\hline & Değerlendirme ölçütleri & $\begin{array}{l}\text { En yüksek puan alan geçmiş } \\
\text { dönem görüntüsü }\end{array}$ & $\begin{array}{l}\text { En yüksek puan alan } \\
\text { günümüz görüntüsü }\end{array}$ \\
\hline \multirow{3}{*}{ 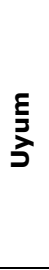 } & Fotoğrafın çevresiyle uyumu & İstiklal Caddesi (G2) & $\begin{array}{c}\text { İstiklal Caddesi (G2) } \\
\text { Atatürk Kültür Merkezi (G5) }\end{array}$ \\
\hline & $\begin{array}{c}\text { Topografya, bitkisel öğeler ve yapısal } \\
\text { öğelerin birbiriyle uyumu }\end{array}$ & $\begin{array}{l}\text { İstiklal Caddesi (G2) } \\
\text { Cumhuriyet Caddesi (G6) }\end{array}$ & Atatürk Kültür Merkezi (G5) \\
\hline & $\begin{array}{c}\text { Alanın mevcut öğeleriyle kimlik (karakter) } \\
\text { kazanması }\end{array}$ & $\begin{array}{c}\text { İstiklal Caddesi (G2) } \\
\text { Atatürk Kültür Merkezi (G5) }\end{array}$ & Atatürk Kültür Merkezi (G5) \\
\hline \multirow{6}{*}{ 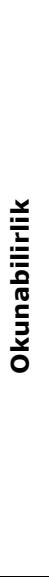 } & Peyzajın algılanabilirliği & $\begin{array}{c}\text { Gezi Parkı (G3) } \\
\text { Atatürk Kültür Merkezi (G5) } \\
\text { Cumhuriyet Caddesi (G6) }\end{array}$ & Gezi Parkı (G3) \\
\hline & Algıya açık yönlenme & $\begin{array}{c}\text { Gezi Parkı (G3) } \\
\text { Cumhuriyet Caddesi (G6) }\end{array}$ & Gezi Parkı (G3) \\
\hline & Algıya kapalılık (sınırlıık) & - & $\begin{array}{c}\text { İstiklal Caddesi (G2) } \\
\text { Atatürk Kültür Merkezi (G5) }\end{array}$ \\
\hline & Ayırt edici öğelerin varlığı & Atatürk Kültür Merkezi (G5) & Atatürk Kültür Merkezi (G5) \\
\hline & Alanda bulunan özgün öğelerin varlığı & $\begin{array}{c}\text { Taksim Maksemi (G4) } \\
\text { Atatürk Kültür Merkezi (G5) }\end{array}$ & $\begin{array}{c}\text { Gezi Parkı (G3) } \\
\text { Atatürk Kültür Merkezi (G5) } \\
\text { Cumhuriyet Caddesi (G6) }\end{array}$ \\
\hline & Bakımlı temiz alan varlığı & Cumhuriyet Caddesi (G6) & $\begin{array}{c}\text { Gezi Parkı (G3) } \\
\text { Cumhuriyet Caddesi (G6) }\end{array}$ \\
\hline \multirow{4}{*}{ 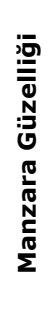 } & Görüntünün açıklığı(seçilebilirlik) & Atatürk Kültür Merkezi (G5) & Atatürk Kültür Merkezi (G5) \\
\hline & Görülebilen alanın büyüklüğü & Gezi Parkı (G3) & $\begin{array}{c}\text { Gezi Parkı (G3) } \\
\text { Atatürk Kültür Merkezi (G5) }\end{array}$ \\
\hline & Görüntünün derinliği & $\begin{array}{l}\text { İstiklal Caddesi (G2) } \\
\text { Gezi Parkı (G3) }\end{array}$ & - \\
\hline & $\begin{array}{c}\text { Görüntünün netliği (engelleyen unsurların } \\
\text { olmaması) }\end{array}$ & Gezi Parkı (G3) & Atatürk Kültür Merkezi (G5) \\
\hline \multirow[b]{2}{*}{ 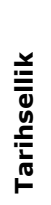 } & Tarihi öğelerin varlığı & Taksim Maksemi (G4) & - \\
\hline & Tarihi öğelerin korunmuşluğu & $\begin{array}{l}\text { İstiklal Caddesi (G2) } \\
\text { Taksim Maksemi (G4) }\end{array}$ & - \\
\hline \multirow{3}{*}{$\begin{array}{l}\grave{0} \\
\stackrel{0}{c} \\
\grave{0}\end{array}$} & İnsan ölçüsüne uygunluk & $\begin{array}{c}\text { Taksim Maksemi (G4) } \\
\text { Cumhuriyet Caddesi (G6) }\end{array}$ & Atatürk Kültür Merkezi (G5) \\
\hline & Kent mobilyası varlığı ve uyumu & - & Gezi Parkı (G3) \\
\hline & $\begin{array}{c}\text { Renk, malzeme, doku açısından hoşnut } \\
\text { olma durumu }\end{array}$ & Taksim Maksemi (G4) & - \\
\hline
\end{tabular}

Genel olarak yapılan değerlendirmelerde ise (Şekil 4, Tablo 10), tarihi öğeler ve topografya ve bitkisel öğelerin uyumlu bir bütünlük oluşturduğu, algılanabilir, renk, malzeme, doku açısından düzenli bir uyum ve konforun tasarlandığı görünümler görsel açıdan olumlu olarak 
değerlendirilmiştir. Buna karşın, kat yüksekliği, cephe birliği, renk, doku ve malzeme gibi özellikler açısından alanın tarihi görünümü ile uyumlu bir birlikteliğin sağlanamadığı ve mekansal bütünlüğün algılanamadığı görüntüler ise görsel peyzaj kalitesi açısından düşük olarak değerlendirilmiştir. Altınçekiç vd. (2014) ve URL (2010) gibi Taksim meydanını içeren çalışmalarda da benzer noktalara vurgu yapılmıştır.

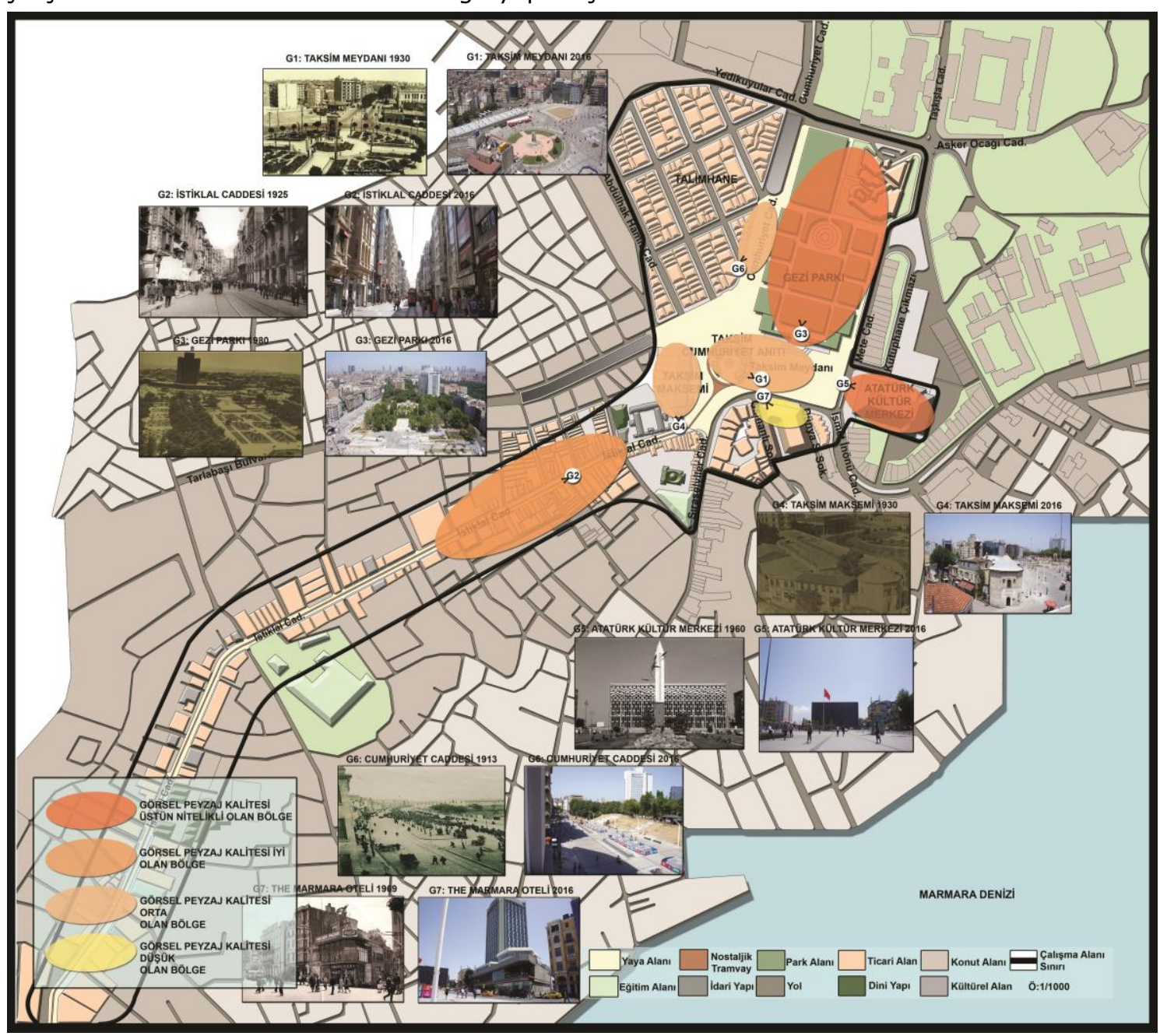

Şekil 4. Araştırma alanının görsel peyzaj analizi haritası

Tablo 10. Görüntülere ilişkin genel değerlendirme

\begin{tabular}{|c|c|c|c|c|c|c|c|c|}
\hline \multirow{2}{*}{ Görüntü No } & \multicolumn{4}{|c|}{ Puan Aralığı (Geçmiş Dönem) } & \multicolumn{4}{|c|}{ Puan Aralığı (2016 yılı görünümü) } \\
\hline & $\begin{array}{l}<120 \\
\text { Düşük }\end{array}$ & $\begin{array}{c}120-240 \\
\text { Orta }\end{array}$ & $\begin{array}{c}240-360 \\
\dot{I}_{y i}\end{array}$ & $\begin{array}{c}360> \\
\text { Yüksek }\end{array}$ & $\begin{array}{l}<120 \\
\text { Düşük }\end{array}$ & $\begin{array}{c}120-240 \\
\text { Orta }\end{array}$ & $\begin{array}{c}240-360 \\
\dot{I}_{y i}\end{array}$ & $\begin{array}{c}\text { 360> } \\
\text { Yüksek }\end{array}$ \\
\hline Görüntü 1 & & & $\sqrt{ }$ & & & $\sqrt{ }$ & & \\
\hline Görüntü 2 & & & & $\sqrt{ }$ & & & $\sqrt{ }$ & \\
\hline Görüntü 3 & & & & $\checkmark$ & & & & $\checkmark$ \\
\hline Görüntü 4 & & & & $\sqrt{ }$ & & $\sqrt{ }$ & & \\
\hline Görüntü 5 & & & & $\sqrt{ }$ & & & & $\sqrt{ }$ \\
\hline Görüntü 6 & & & & $\sqrt{ }$ & & $\sqrt{ }$ & & \\
\hline Görüntü 7 & & $\sqrt{ }$ & & & v & & & \\
\hline
\end{tabular}


Çalışma kapsamında elde edilen en önemli sonuçlardan biri de, geçmiş döneme ilişkin görüntülerin, günümüz görünümlerine oranla görsel peyzaj kalitesi açısından daha fazla oranda tercih edilmesi olmuştur. Buna göre geçmiş döneme ilişkin olarak, Taksim Meydanı görsel peyzaj kalitesi açısından iyi, İstiklal Caddesi, Gezi Parkı, Taksim Maksemi, Atatürk Kültür Merkezi ve Cumhuriyet Caddesi'ne ilişkin G2,G3,G4,G5, ve G6 nolu görüntüler ise görsel peyzaj kalitesi açısından çok yüksek çıkmıştır. Günümüz görüntüleri görsel peyzaj kalitesi açısından değerlendirildiğinde ise, The Marmara Oteli'nin yer aldığı 7 nolu görüntü düşük, G1, G4, G6 nolu görüntüler orta, İstiklal Caddesi'nin yer aldığı 2 nolu görüntü iyi, Gezi parkı ve Atatürk Kültür Merkezi'nin yer aldığı 3 ve 5 nolu görüntüler ise yüksek olarak tercihedilmiştir. Bu sonuç zaman içerisinde alan ve yakın çevresine ilişkin görsel algının giderek zayıfladığını göstermiştir. Sonuç olarak Taksim meydanı ve yakın çevresi İstanbul için önemli bir Landmark niteliği taşımaktadır. Özellikle de kullanıcı yoğunluğu, sanatsal, kültürel, rekreasyonel, ekonomik gibi pek çok aktivite çeşitliliği ve tarihsel geçmiş gibi pek çok açılardan en önemli meydanlardan birini oluşturmaktadır. Bütün bu özelliklere sahip alan ve yakın çevresinin uyum, okunabilirlik, konfor, tarihsellik ve manzara güzelliği gibi parametreler açısından çevre kimliği ile bütünleştirildiği tasarım ve uygulamalara önem verilmesi alanın görsel yönden kalitesini arttıracaktır.

Not: Bu çalışma Namık Kemal Üniversitesi Peyzaj Mimarlığı Anabilim Dalı'nda yürütülmüş olan Yüksek Lisans tezinden yararlanılarak hazırlanmıştır.

\section{KAYNAKLAR}

Altınçekiç, H.S.Ç. (2000). İstanbul Metropolü'nde meydanların rekreasyon işlev yönünden önemi üzerine araştırmalar. Yayımlanmamış Doktora Tezi, İstanbul Üniversitesi Fen Bilimleri Enstitüsü, Peyzaj Mimarlığı Anabilim Dalı, İstanbul.

Altınçekiç, H.S.Ç. Ergin, B., Tanfer, M., (2014). Tarihsel süreç içinde kent kimliğinin mekânsal kalite değerlendirmesi üzerine bir araştırma (Taksim Meydanı). Artvin Çoruh Üniversitesi Orman Fakültesi Dergisi, 15(2): 132-148.

Apak, H., Erdönmez , E. (2015). Kentsel bellekte meydan, San Marco Meydanı. Kent Akademisi, 8(3): 73-96.

Atalay, N. (2011). Kent meydanı: kamusal-estetik çerçevede eleştirel bir değerlendirme. Yayımlanmamış Doktora Tezi, İstanbul Teknik Üniversitesi, Fen Bilimleri Enstitüsü, Mimarlık Anabilim Dalı, İstanbul.

Erdönmezer, E. (2014). Kamusal alanların biçimlenmesi, İTU Vakfı Dergisi, 63,İstanbul.

İnceoğlu, M., Aytuğ, A., (2009). Kentsel mekânda kalite kavramı. Megaron Dergisi, 4(3): 131-146.

Kır,İ. (2009). Kent meydanlarının kent kimliği üzerine etkileri; İzmir Örneği. Yayımlanmamış Yüksek Lisans Tezi, Ege Üniversitesi Fen Bilimleri Enstitüsü, Peyzaj Mimarlığı Anabilim Dalı, İzmir.

Kıroğlu, E. (2007). Erzurum kenti ve yakın çevresindeki bazı rekreasyon alanlarının görsel peyzaj kalitesi yönünden değerlendirilmesi. Yayımlanmamış Yüksek Lisans Tezi, Atatürk Üniversitesi Fen Bilimleri Enstitüsü, Peyzaj Mimarlığı Anabilim Dalı, Erzurum.

Kiper, T. Korkut, A., Üstün Topal, T., (2016). Kıyıköy örneğinde ekoturizm planlamasına yönelik görsel peyzaj analizinin uygulanması. NKUBAP.00.18.AR.14.10 No'lu Namık Kemal Üniversitesi Bilimsel Araştırma Projesi.

Kuğu Tüfekçioğlu, H. (2008). Tarihsel çevrede görsel peyzaj kalite değerlendirmesi İstanbul Yedikule örneği. Yayımlanmamış Yüksek Lisans Tezi, İstanbul Teknik Üniversitesi Fen Bilimleri Enstitüsü, Peyzaj Mimarlığı Anabilim Dalı, İstanbul.

Müderrisoğlu, H. ve Eroğlu, E. (2006). Bazı ibreli ağaçların kar yükü altında görsel algılanmasındaki farklılıklar. Süleyman Demirel Üniversitesi Orman Fakültesi Dergisi, A (1):136-146.

Ölmez Kalender, S., Demiroğlu, D. (2011). Tarihi süreç içerisinde sivas kent meydanı'nın irdelenmesi. İnönü Üniversitesi Sanat ve Tasarım Dergisi, 1(3):354-365.

Özer, M.N. ve Ayten, M.A. (2005). Kamusal Odak Olarak Kent Meydanları. Planlama. 3: 96103.

Özhancı E. ve Yılmaz H. (2011). Rekreasyon Alanlarının Görsel Peyzaj Kalitesi Yönünden Değerlendirilmesi; Erzurum Örneği. Iğdır Ün. Fen Bilimleri Enst. Dergisi, 1(2): 67-76.

Özkan, G.D., Alpak, E.M., Özbilen, A. (2015). Visual preferences in urban scenes: evaluation of perception change in the Trabzon City 2-4 February 2015- Istanbul, Turkey 
Proceedings of INTCESS15- 2nd International Conference on Education and Social Sciences.

Sancar, C., Acar, C. (2016). Türkiye'de kent peyzajının yeni yüzleri olarak meydanlar: Trabzon-Ortahisar "Atatürk Alanı" Dönüşüm Projesi . İnönü Üniversitesi Sanat ve Tasarım Dergisi. 6(13): 57-73.

Taşcı, H. (2014). Bir hayat tarzı olarak şehir mekan meydan. Kaknüs Yayınları, İstanbul.

URL, 2010. www.skb.gov.tr/wp-content/uploads/2012/09/İSTANBUL-MEYDANLARI.pdf. (Erişim tarihi: 14.05.2018).

\section{EXTENDED ABSTRACT}

In addition to their function as a gathering/scattering center and visual appeal in the city, the squares especially have become places of meeting and gathering for the people of the city as well as for other visitors. Thus, they have become multipurpose spaces where people are away from the chaos of the city, have the opportunity to relax and rest, see each other and share the events in the city. At this point, the squares called the agora, forum, plaza, campo, piaza, grand place, from the ancient times until the early periods of the Republic, were an important part of urban culture that reflects philosophy and life style of the cities. Nowadays, however, the squares have turned into intersection or parking spaces for cities that have grown with technological developments, changing and transforming living standards and rapid population growth. At this point, the squares have differentiated in terms of function and form over time, and have gained effective characteristics with their spatial qualities and characteristic features and also visually with their different designs. Hence, physical, visual and social interactions have been observed on the squares with the transformations emerging on the whole of image, identity and meaning. In this case, the user's perception of the visual quality of the surrounding area is also very important. Otherwise, as the user's perception weakens, the relationship between the person and the environment gradually decreases and causes the environment not to be preferred. In this context, the changes in Taksim Square, which has an important historical accumulation for the city of Istanbul, and its surrounding neighborhoods, related to visual and landscape quality of past and present state were examined in this article. In this direction, perceptual differences related to the visual landscape were determined in terms of the old and new urban aspects of the area and the answers to the following questions were sought:

- Which is preferred between the past and present appearance of Taksim square and its close surroundings?

- What are the areas of the Taksim square and its surrounding areas that have a visual appeal in terms of past and present appearance?

The main material of the study is the Taksim Square and its near surroundings located in the district of Beyoğlu in Istanbul. The selected area is approximately $210,000 \mathrm{~m}^{2}$.

Taksim Square and its immediate surroundings were chosen as the research area since it is a symbol of Istanbul city identity, it has important transportation links, it has a historical monumental structure and traditional architectural texture, it has commercial spaces, it is a landmark for Istanbul city and it has a demand for intensive usage.

Visual landscape analysis method was used in the study. In this context, past and present images consisting of 7 shots belonging to Taksim Square, Taksim Maksemi, İstiklal Caddesi, Cumhuriyet Caddesi, Gezi Park, Atatürk Cultural Center and The Marmara Hotel, which are important in terms of urban identity, were used. Images that offers broad visibility and places that have made important contributions to the urban identity from the past to the present day have become important factors in the selection of photos. The past and present images of the 7 selected photographs were evaluated by 12 expert groups with the 5 Likert Scale (1 lowest, 5 highest) based on 5 main 18 subparameters. The parameters used are given below.

\begin{tabular}{|l|c|}
\hline Main Parameters & Subparameters \\
\hline Harmony & Harmony with the periphery of the photo \\
\hline
\end{tabular}




\begin{tabular}{|c|c|}
\hline & $\begin{array}{l}\text { Harmony between topography, herbal items and structural } \\
\text { items }\end{array}$ \\
\hline & $\begin{array}{l}\text { Identity acquisition of the area by means of its existing } \\
\text { elements }\end{array}$ \\
\hline \multirow{6}{*}{ Legibility } & Perceivability of landscape \\
\hline & Perceivable explicit routing \\
\hline & Imperceptibility (limitedness) \\
\hline & Presence of distinguishing items \\
\hline & Presence of original items in the field \\
\hline & Presence of preserved clean area \\
\hline \multirow{4}{*}{ Landscape Beauty } & Display clarity (selectivity) \\
\hline & Size of visible area \\
\hline & Depth of view \\
\hline & Visual clarity (no obstacles) \\
\hline \multirow{2}{*}{ Historicity } & Presence of historical items \\
\hline & Preservation of historical items \\
\hline \multirow{3}{*}{ Comfort } & Compliance with human dimension \\
\hline & City furniture existence and image effect \\
\hline & Satisfaction with color, material, texture \\
\hline
\end{tabular}

Percentage averages of the scores given by the expert group to the evaluation criteria for each of the identified images belonging to the past and the present are given in the form of schedules with statistical analysis.

According to the scores given by the expert group in the schedules, the lowest and highest scoring criteria were determined and general evaluation was made accordingly.

In the general evaluation, the 7th image where The Marmara Hotel is located is low, 1st, 4th and 6th images are medium, and 2nd image located in the Istiklal Caddesi is good in terms of visual quality. Taking these assessments into consideration, it was seen that the expert group preferred the city's old appearance at a higher than the new appearance level in terms of visual landscape quality. At this point, new images are preferred at a lower level, due to reasons such as the disappearance of historical structures or the loss of its characteristics and the lack of a harmonious coexistence between old and new urban texture. Thus, perceivability is gradually weakening from the past to the present day. At this point, especially the support and strengthening of the local, original architecture with identity is highly influential in the formation of an effective character in visual landscape.

Especially in this point, the support and strengthening of the regional, original and identity architecture is very influential in the formation of an effective character in visual landscape. 